\title{
Evaluation of serum soluble E-selectin in breast cancer
}

\author{
Halla Mohamed Ragab ${ }^{1 *}$, Mie Afify ${ }^{1}$, Nervana Samy ${ }^{1}$, Nabila Abd El Maksoud ${ }^{1}$, HebatAllah Mohamed Shaaban ${ }^{2}$ \\ ${ }^{\mathbf{1} B i o c h e m i s t r y ~ D e p a r t m e n t, ~ G e n e t i c ~ E n g i n e e r i n g ~ a n d ~ B i o t e c h n o l o g y ~ R e s e a r c h ~ D i v i s i o n, ~ N a t i o n a l ~ R e s e a r c h ~ C e n t e r, ~ D o k k i, ~ G i z a ~ E g y p t . ~}$ \\ ${ }^{2}$ Pathology Department, National Cancer Institute, Cairo University, Cairo Egypt.
}

\section{ARTICLE INFO \\ Article history: \\ Received on: $14 / 10 / 2016$ \\ Accepted on: 18/12/2016 \\ Available online: $30 / 03 / 2017$}

Key words:

Adhesion molecules, E-

selectin, Breast Carcinoma,

Tumor Grade, Prognosis,

Molecular types, Gene

expression.

\begin{abstract}
Breast cancer is a highly metastatic disease even after surgical removal of the primary tumor. Metastasis is the main cause of death in breast cancer patients. The aim of the study was to assess the concentration of E-selectin in serum and tissue from breast cancer patients and women suffering from benign breast disease to determine its prognostic value in these diseases. This study was conducted on three groups of patients: Group A included 92 breast cancer patients, Group B included 25 patients with benign breast and group C (the control group) included 16 subjects. Blood samples were withdrawn for the estimation of serum E-selectin by ELISA and the gene expression of E-selectin was examined in Breast tissue samples. The results showed that serum level of Eselectin was highly significantly increased in malignant group as compared to benign and control groups $(\mathrm{P}<0.05)$, it increased with the progression of disease. E-selectin serum level showed nonsignificant difference between benign and control groups. E-selectin gene was expressed in $76.1 \%$ in malignant tissues, in $44.0 \%$ in benign tissues and in only one case in control group (6.2\%). These results show highly significant difference between the diseased groups and the controls. The expression of E-selectin significantly correlated with aggressive tumor behavior. In conclusion, we found that the assessment of the adhesion molecule E-selectin in women with breast cancer can be added to the panel of tests that monitor the progress of the disease.
\end{abstract}

\section{INTRODUCTION}

Breast cancer is the most commonly diagnosed cancer among females, most cases dies from metastatic disease. Angiogenesis plays an important role in the growth of malignant tumors and the formation of distant metastases (American Cancer Society, 2015; Carmeliet, 2003). Vascular endothelial cells are of particular importance in the early stages of this process, owing to their adhesive properties, which maintains close contact between cells. This cell-to-cell adhesion, and adhesion to macromolecules of the extra cellular matrix (ECM), is possible because of the presence of cell adhesion molecules expressed on the external surface of the endothelium (Endemann and Schiffrin, 2004).

\footnotetext{
* Corresponding Author

Halla M. Ragab, Prof. of Biochemistry, National Research Center

(NRC), El Behouth St., Dokki, Giza Egypt. P.O. Box 12311,

Dokki, Cairo, Egypt. Tel: 01009219032, Fax: 002-02-33370931.

E-mail:hmragab@yahoo.com
}

Many researchers admitted the role of adhesion molecules in the processes of angiogenesis and metastases. It is believed that their concentration in tissue and blood may help in early diagnosis, staging and follow up of treatment of cancer (Byrne et al., 2000). Selectins are cellular adhesion molecules expressed on the cell surface and help in adhesion and cellular interaction. Selectins were named due to the presence of a lectin domain in the molecule that bind to cell-surface ligands and function as adhesion molecules. It is named according to site of origin; E-selectin originates in endothelium, L-selectin from lymphocytes and Pselectin from platelets (Springer, 1994). E-selectin expression is absent on normal endothelial cells, but the expression is induced rapidly in response to cytokines such as tumor necrosis factor $\alpha$ (TNF- $\alpha$ ) and interleukin (IL)-1 $\beta$; it is expressed in inflamed and angiogenic blood vessels, so as tumor vasculature is in a state of inflammation; adhesion molecules are overexpressed on its endothelial lining. It plays a significance role in formation of cancer metastasis (Burdick et al., 2001; Shamay et al., 2015). 
Increased concentrations of E-selectin in case of cancer may be a prognostic marker in the course of many neoplastic diseases (Siegel and Malmsten, 1997). Several tumor cells which were isolated from different cancers express high levels of Eselectin ligand which is sialyl Lewis $\mathrm{X}$ on their cell surface and have the capacity to adhere to endothelial surface that express Eselectin leading to tumor dissemination (Gout et al., 2008; Barthel et al., 2007).

The aim of the study was to assess the concentration of E-selectin in serum and tissue from breast cancer patients and women suffering from benign breast disease to determine its prognostic value in these diseases.

\section{PATIENTS AND METHODS}

This study was conducted on 133 individuals; the studied group was divided into three groups: group A included 92 breast cancer patients with age ranged from (23-70 years). Group B included 25 patients with benign breast and their age ranged from (21-43 years) and group C (the control group) included 16 subjects with age ranged from (20-65 years). The breast cancer patients were admitted to National Cancer Institute, Cairo, Egypt. Our study design was approved by Medical Research Ethical Committee - National research center, Cairo, Egypt (Approval No.14-031). An informed consent was taken from each participant before enrollment in the study. Clinical staging was expressed according to the TNM classification system based on evaluation of findings of physical examination. Routine laboratory tests, radiological reports (chest X-ray, liver echography, bone scan and computed tomography) and pathological assessment of the tissue removed was done to determine the type of the tumor and its grade according to Bloom and Richardson. The size of the tumor and the number of lymph nodes were also determined. The study protocol had been approved by the local Ethics Committee and subjects gave written consent to participate in the present study.

The benign breast disease group underwent full history and clinical data were recorded for all patients. They underwent operative biopsy and histopathological examination of all biopsies revealed, fifteen cases with fibroadenosis, ten cases with fibroadenoma. Ten normal healthy women were included in this work as control group.

\section{Samples}

\section{Serum samples}

Ten-ml fasting Blood samples were taken from cancer patients before receiving any line of treatment, as well as from patients with benign tumors and control. The blood was allowed to clot and sera were separated by centrifugation for $10 \mathrm{~min}$ at 3000 r.p.m, divided into several aliquots and stored at $-80^{\circ} \mathrm{C}$ until assayed.

\section{Tissue samples}

Breast tissue samples (both benign and malignant) were obtained directly from the operating theater, after surgical removal of the tumor mass. Immediately, the tissue sample was washed by ice cold saline. Fat, necrotic tissues and skin were rapidly dissected from the tissue of interest.

The remaining tumor tissue was divided into two parts, one part for pathological examination and the other part was immediately stored in liquid nitrogen for determination of Eselectin expression.

\section{Methods}

1-Determination of serum E-selectin by ELISA technique using kit provided from Quantikine (R\&D systems U.K).

2- Determination of E-selectin in breast tissue:

\section{RNA extraction}

Tissue homogenization in lysis buffer was done. Then total RNA was extracted from the homogenate using SV total RNA extraction kit provided from Promega Corporation, Madison,WI, USA. The amount of RNA was quantitated by reading the Optical Density (OD) at wave length of $260 \mathrm{~nm}$ by using spectrophotometer.

\section{Primers synthesis}

One primer sets was prepared, using the oligo-1000 DNA synthesizer (Beckman, California, USA). The primer sequences used for amplification of E-selectin were:

\section{F2: 5 CCAAAGCTGCTCTAGCC 3}

\section{R2: 5 CTGCTGTTCTGATCCTTATCAC 3}

\section{RT-PCR experiment}

RT- PCR was done using the extracted RNA for detection of the expression of E-selectin gene. RNA was reverse transcribed using $12.5 \mu \mathrm{l}$ oligo $(\mathrm{dT})_{18}$ primer and was denatured at $70^{\circ} \mathrm{C}$ for 2 minutes. The denatured RNA was placed on ice and 6.5 $\mu \mathrm{l}$ of reverse transcription mixture containing $50 \mathrm{mM}$ Tris $\mathrm{HCl}$ pH8.3, $50 \mathrm{mM} \mathrm{KCl}, 1.5 \mathrm{mM} \mathrm{Mg} \mathrm{Cl}, 0.5 \mathrm{mM}$ of each dNTP, 1 $\mathrm{U} / \mu \mathrm{l}$ RNAse inhibitor and 200 Units of MMLV reverse transcriptase was added. Then, the reaction tube was placed at $42^{\circ} \mathrm{C}$ for $1 \mathrm{~h}$ followed by heating to $92^{\circ} \mathrm{C}$ to stop the reaction. Then PCR reaction was performed by adding the PCR mix to a final volume of $100 \mu \mathrm{l}$.

The PCR mix contained $10 \mathrm{mmol} / \mathrm{l}$ Tris- $\mathrm{HCl} \mathrm{pH} 8.3,50$ $\mathrm{mM} \mathrm{KCl}, 1.5 \mathrm{mM} \mathrm{MgCl}_{2}$, and $0.001 \%$ gelatin, $250 \mu \mathrm{M}$ dNTPs mix, 2.5U Taq polymerase, and $100 \mu \mathrm{M}$ of each primer. The reaction mixture was then subjected to 40 cycles of $95^{\circ} \mathrm{C}$ for 1 $\min , 55^{\circ} \mathrm{C}$ for $1 \mathrm{~min}$, and $72{ }^{\circ} \mathrm{C}$ for $2 \mathrm{~min}$. After the last cycle, a final extension at $72^{\circ} \mathrm{C}$ for $10 \mathrm{~min}$ was done.

\section{Agarose gel electrophoresis}

All the PCR products of all cases were electrophoresed on $2 \%$ agarose gel stained with ethidium bromide and visualized by UV transilluminator. The expected length of the PCR product was 163 bp (Figure1, 2). 


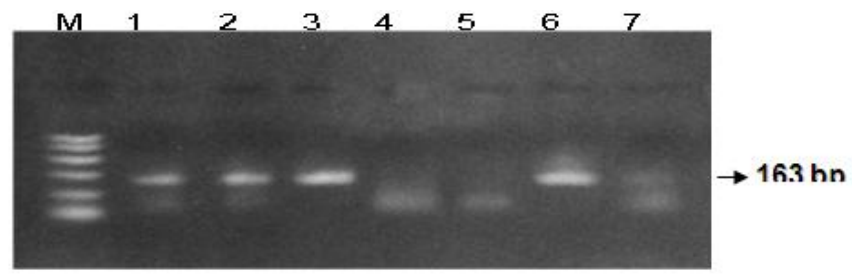

Fig. 1: An agarose gel electrophoresis 2\% stained with ethidium bromide showing the PCR product of E- selectin gene expression at $163 \mathrm{bp}$ of benign breast cancer.

Lanes 1- 3, 6

: Molecular marker $(1000,750,500,300,150,50 \mathrm{bp})$

Lanes 4,5

Negative cases, Lane 7 : Negative control.

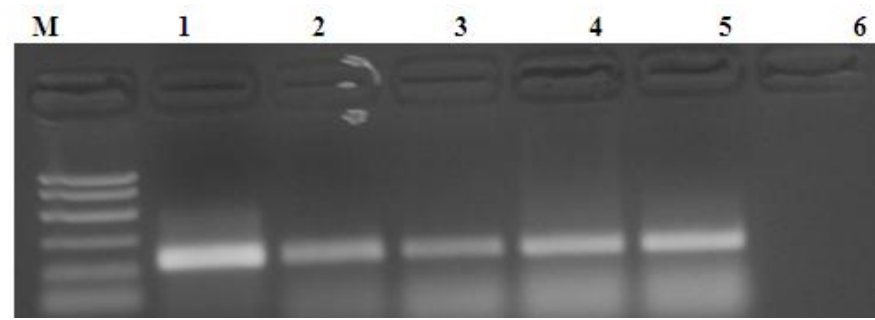

Fig. 2: An agarose gel electrophoresis 2\% stained with ethidium bromide showing the PCR product of E- selectin gene expression at $163 \mathrm{bp}$ of malignant breast cancer.

Lanes 1- 5

Lane 6

: Molecular marker (1000, 750, 500, 300, 150, 50 bp),

Positive cases.

: Negative control.

\section{Statistical Analysis}

Descriptive statistics of the study groups were expressed in the form of mean and standard error (mean \pm SD). Comparative analysis between different groups was applied using student's t test with statistical significance at $(\mathrm{p}<0.05)$.

\section{RESULTS}

The studied group was divided into three groups: group A included 92 breast cancer patients with age ranged from (23-70 years). Group B included 25 patients with benign breast and their age ranged from (21-43 years) and group $\mathrm{C}$ (the control group) included 16 subjects with age ranged from (20-65 years).

-E-selectin gene was expressed in $76.1 \%$ in malignant tissues, in $44.0 \%$ in benign tissues and in only one case in control group $(6.2 \%)$. These results show highly significant difference between the diseased groups and the controls. As regards grades of the malignant breast cancer, the E-selectin gene was expressed in $60.0 \%$ of grade I, $75.6 \%$ of grade II and $40.7 \%$ in grade III. According to the stages of the malignant lesions, the percentage of the positive expression of the E-selectin was $40.6 \%, 78.4 \%$ and $88.9 \%$ in stage I \& II, III and IV respectively. By comparing the results in positive and negative lymph node affection, the serum level as well as the percent of the gene expression of E-selectin was $86.8 \%$ in patients with positive $\mathrm{LN}$ affection, while it was $69.2 \%$ in patients with negative $\mathrm{LN}$ involvement (Table 1). The percentage of E-selectin expression in age groups $<50$ years and $>$ 50 years patients was $65.7 \%$ and $81.5 \%$ respectively. Furthermore, the percentage of E-selectin expression in ER positive and Er negative was $(69.2 \%)$ and $(86.8 \%)$ respectively. By comparing the results of tumor sizes, the serum level as well as the percent of the gene expression of E-selectin was $46.2 \%$ in patients with tumor sizes $<2 \mathrm{~cm}$, while it was $77.4 \%$ in patients with tumor siz $>2 \mathrm{~cm}$. The serum E-selectin levels were significant in patients with tumor size $>2 \mathrm{~cm}$ when compared to those with tumor size $<2 \mathrm{~cm}(\mathrm{P}<0.05)$ (Table 1$)$.

Table 1: Serum level of E-selectin and Frequency of Tissue E-selectin gene in control, benign and malignant groups, and this last further divided into subgroups according to the grade, the stage, the lymph node involvement (LN) and menopausal status.

\begin{tabular}{|c|c|c|c|}
\hline & $\begin{array}{l}\text { No. of } \\
\text { cases }\end{array}$ & $\begin{array}{c}\text { E-Selectin } \\
\text { by PCR }\end{array}$ & $\begin{array}{c}\text { E-Selectin ng/mL } \\
\text { Mean } \pm \text { SD }\end{array}$ \\
\hline \multicolumn{4}{|l|}{ Types of groups } \\
\hline Control ( C ) & 16 & $1(6.2 \%)$ & $35.9 \pm 8.17$ \\
\hline Benign ( B ) & 25 & $11(44.0 \%)$ & $39.6 \pm 9.69$ \\
\hline Malignant ( A ) & 92 & $70(76.1 \%)$ & $110.6 \pm 29.4 *$ \\
\hline \multicolumn{4}{|l|}{ Grading } \\
\hline Grade I & 20 & $12(60.0 \%)$ & $85.61 \pm 10.29$ \\
\hline Grade II & 45 & $34(75.6 \%)$ & $103.61 \pm 11.29$ \\
\hline Grade III & 27 & $11(40.7 \%)$ & $109.9 \pm 24.13$ \\
\hline \multicolumn{4}{|l|}{ Staging } \\
\hline Stage I \& II & 32 & $13(40.6 \%)$ & $69.3 \pm 13.8$ \\
\hline Stage III & 51 & $40(78.4 \%)$ & $94.12 \pm 19.76 \mathbf{a}$ \\
\hline Stage IV & 9 & $8(88.9 \%)$ & $119.9 \pm 21.1 \quad \mathbf{a}$ \\
\hline \multicolumn{4}{|l|}{ LN affection } \\
\hline LN Positive & 60 & $39(81.3 \%)$ & $122.31 \pm 24.3 \mathbf{b}$ \\
\hline LN Negative & 32 & $9(28.1 \%)$ & $82.46 \pm 21.12$ \\
\hline \multicolumn{4}{|l|}{ Age } \\
\hline$<50$ years & 38 & $25(65.7 .7 \%)$ & $81.22 \pm 11.2$ \\
\hline$>50$ years & 54 & $44(81.5 \%)$ & $119.4 \pm 23.73 \mathbf{c}$ \\
\hline \multicolumn{4}{|l|}{ Tumor size } \\
\hline$<2 \mathrm{~cm}$ & 39 & $18(46.2 \%)$ & $78.8 \pm 15.3$ \\
\hline$>2 \mathrm{~cm}$ & 53 & $41(77.4 \%)$ & $115.5 \pm 21.6 \mathbf{d}$ \\
\hline \multicolumn{4}{|l|}{ Estrogen Receptor } \\
\hline ER Negative & 39 & $27(69.2 \%)$ & $121.6 \pm 14.4 \mathbf{e}$ \\
\hline ER Positive & 53 & $46(86.8 \%)$ & $96.6 \pm 13.7$ \\
\hline
\end{tabular}

$* \mathrm{P}$ value $<0.05$ considered significant compared to control.

$\mathbf{a} \rightarrow$ significant $\mathrm{P}<0.05$ when comparing to stage I, II.

$\mathbf{b} \rightarrow$ significant $\mathrm{P}<0.05$ when comparing the nodal status

c $\rightarrow$ significant $\mathrm{P}<0.05$ when comparing the age

d $\rightarrow$ significant $\mathrm{P}<0.05$ when comparing tumor size.

$\mathbf{e} \rightarrow$ significant $\mathrm{P}<0.05$ when comparing Estrogen Receptor

The mean serum level of E-selectin showed highly significant increase in malignant group as compared to benign and control groups $(\mathrm{P}<0.05)$ (the mean levels were 110.6, 39.69 and $35.9 \mathrm{ng} / \mathrm{mL}$ in malignant, benign and control group respectively). E-selectin serum level showed non-significant difference between benign and control groups ( $\mathrm{P}>0.05)$ Meanwhile, the serum level of E-selectin in one and two grades was nearly the same with no statistical difference. Also, the mean serum level of E-selectin was significantly higher in stage III and IV compared to stage I \& II. The serum E-selectin levels were statistically significant in patients with positive lymph node affection when compared to those with no lymph node affection $(\mathrm{P}<0.05)$. Meanwhile, the serum levels of E-selectin in the $>50$ years old patients were significantly elevated than in $<50$ years old patients $(\mathrm{P}<0.05)$, meanwhile, there was a significantly higher serum level of soluble E-selectin in women with ER-negative tumors (Table 1), (figure 1). 


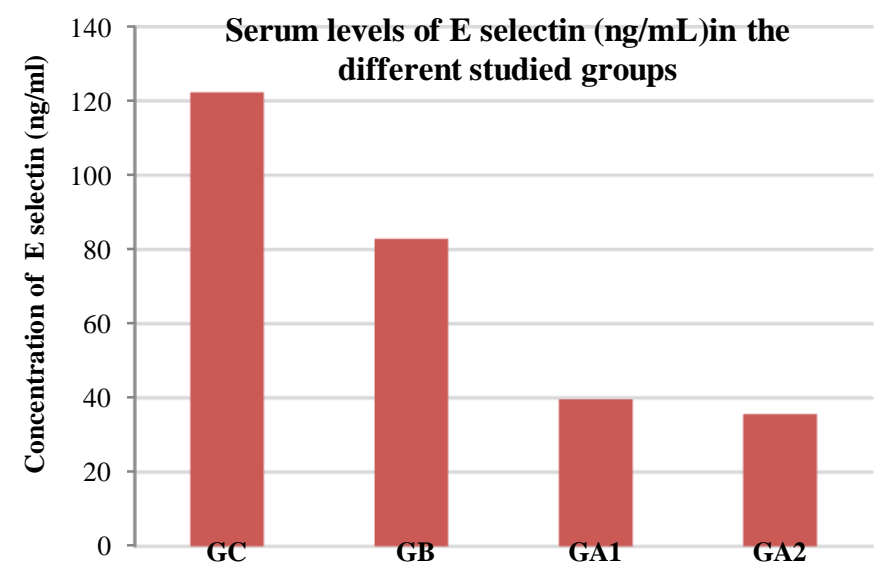

Figure (1) serum levels of E-selectin in different studied groups.

GC: control group GB: Benign group

GA1: malignant group with -ve LN

GA2: malignant group with $+\mathrm{ve} \mathrm{LN}$

\section{DISCUSSION}

Tumor development is a multistage process and long lasting, disturbance between extracellular and intracellular occurs leading to cancer cell spread through tissues and organs causing metastases (Ilyas, 2000). Inspite of efforts made in the diagnosis and treatment of cancer, death from cancer remains high due to distant metastases (Ahmad and Hart, 1997).

In this study E-selectin was significantly increased in serum of patients of breast cancer patients compared to benign group patients and controls. Also E-selectin was expressed significantly in breast cancer tissues compared to benign tissues, both serum and E-selectin expression were significantly elevated as the disease progress in breast cancer patients. In accordance with our findings, studies by other authors have also reported significantly elevated E-Selectin levels in patients with breast cancer (Narita et al., 1996; Shirure et al., 2011; Tozeren et al., 1995). It was stated that vascular adhesion cascade occurs at the blood vessels around the premetastatic region and this is accompanied by E-selectin expression and activation, thereby assisting in the successive shear-resistant adhesion and transendothelial migration of circulating cancer cells to the target organs (Julien et al., 2011). Research studies revealed that selectins expression were increased in many cancers as ovarian cancer (Dong et al., 2008), chronic myeloid leukemia (Kiersnowska-Rogowska et al., 2006), lung cancer (Izycka et al., 2005) and their levels were related to disease progression.

Eichbaum et al. (Eichbaum et al., 2004) investigated the value of soluble and solid states of E-selectin as a potential cancer biomarker for early detection, prognosis, and monitoring, they reported that E-selectin has soluble form (sE-selectin) that can be detected in the blood; it is result of enzymatic cleavage of the external domain or shedding of damaged endothelial cells. It can be detected by ELISA and it correlates with disease progression and formation of metastases. It can be used as prognostic marker post-operatively O'Hanlon et al (O'Hanlon et al., 2002) stated that E-selectin is engaged in the adhesion of breast cancer cells and plays a significant role in tumor dissemination which involves neoplastic metastases; it plays a role in tumor cell-leucocyte aggregation and their interaction with endothelial cells. sLex and sLa are the ligands for E-selectin on metstatic cell surface. Also, tumor cells induce the activation of many cytokines as Il-6, IL-B1 anf TNF alpha which are responsible for expression of E-selectin on tumor cells surface and leads to activation of endothelial cells (Eichbaum et al., 2004; McEver, 1997; Thielemann et al., 2014).

In conclusion, we found that the assessment of the adhesion molecule E-selectin in women with breast cancer can be added to the panel of tests that monitor the progress of the disease.

\section{ACKNOWLEDGEMENTS}

This work was financially supported by the National Research Center, Cairo, Egypt.

Conflict of interest: The authors declare that they have no conflicts of interest.

\section{REFERENCES}

American Cancer Society. Cancer Facts \& Figures. Atlanta: American Cancer Society, 2015.

Carmeliet P. Angiogenesis in health and disease. Nat Med, 2003; 9(6): 653-660.

Endemann DH, Schiffrin EL. Endothelial dysfunction. J Am Soc Nephrol, 2004; 15(8): 1983-1992.

Byrne GJ, Ghellal A, Iddon J, Blann AD, Venizelos V, Kumar $\mathrm{S}$, et al. Serum soluble vascular cell adhesion molecule-1: role as a surrogate marker of angiogenesis. J Natl Cancer Inst, 2000; 92(16): 13291336.

Springer TA. Traffic signals for lymphocyte recirculation and leukocyte emigration: the multistep paradigm. Cell, 1994; 76(2): 301-314.

Burdick MM, McCarty OJ, Jadhav S, Konstantopoulos K. Cellcell interactions in inflammation and cancer metastasis. IEEE Eng Med Biol Mag, 2001; 20(3): 86-91.

Shamay Y, Raviv L, Golan M, Voronov E, Apte RN, David A. Inhibition of primary and metastatic tumors in mice by E-selectin-targeted polymer-drug conjugates. J Control Release, 2015; 217: 102-112.

Siegel G, Malmsten M. The role of the endothelium in inflammation and tumor metastasis. Int J Microcirc Clin Exp, 1997; 17(5): 257-272.

Gout S, Tremblay PL, Huot J. Selectins and selectin ligands in extravasation of cancer cells and organ selectivity of metastasis. Clin Exp Metastasis, 2008; 25(4): 335-344.

Barthel SR, Gavino JD, Descheny L, Dimitroff CJ. Targeting selectins and selectin ligands in inflammation and cancer. Expert Opin Ther Targets, 2007; 11(11): 1473-1491.

Ilyas M. Adhesion molecule expression in breast cancer: the phoenix in tumour metastasis. J Pathol, 2000; 190(1): 3-5.

Ahmad A, Hart IR. Mechanisms of metastasis. Crit Rev Oncol Hematol, 1997; 26(3): 163-173.

Narita T, Kawasaki-Kimura N, Matsuura N, Funahashi $H$, Kannagi R. Adhesion of Human Breast Cancer Cells to Vascular Endothelium Mediated by Sialyl Lewis \&supx; /E-selectin. Breast Cancer, 1996; 3(1): 19-23.

Shirure VS, Henson KA, Schnaar RL, Nimrichter L, Burdick MM. Gangliosides expressed on breast cancer cells are E-selectin ligands. Biochem Biophys Res Commun, 2011; 406(3): 423-429.

Tozeren A, Kleinman HK, Grant DS, Morales D, Mercurio AM, Byers SW. E-selectin-mediated dynamic interactions of breast- and colon- 
cancer cells with endothelial-cell monolayers. Int J Cancer, 1995; 60(3): 426-431.

Julien S, Ivetic A, Grigoriadis A, QiZe D, Burford B, Sproviero $\mathrm{D}$, et al. Selectin ligand sialyl-Lewis $\mathrm{x}$ antigen drives metastasis of hormone-dependent breast cancers. Cancer Res, 2011; 71(24): 7683-7693.

Dong $\mathrm{Y}$, Guo $\mathrm{M}$, Wang $\mathrm{Z}$. Clinical significance of measurements of changes of serum e-cad, sICAM-I, L-Selectin and VEGF levels after operation in patients with ovarian cancer. Fangshe Mianyixue Zazhi, 2008; 21: 268-270.

Kiersnowska-Rogowska B, Izycka A, Jablonska E, Rogowski F, Parfienczyk A. Estimation of L-selectin expression on neutrophils and level of soluble L-selectin form in serum of patient with chronic myelogenic leukemia. Przegl Lek, 2006; 63(9): 756-758.

Izycka A, Jablonska E, Izycki T, Chyczewska E. Expression of L-selectin on the surface of neutrophils stimulated by TNF-alpha and level of sL-selectin in serum of patients with lung cancer. Pol Merkur Lekarski, 2005; 18(103): 62-65.

Eichbaum MH, de Rossi TM, Kaul S, Bastert G. Serum levels of soluble E-selectin are associated with the clinical course of metastatic disease in patients with liver metastases from breast cancer. Oncol Res, 2004; 14(11-12): 603-610.
O'Hanlon DM, Fitzsimons H, Lynch J, Tormey S, Malone C, Given HF. Soluble adhesion molecules (E-selectin, ICAM-1 and VCAM1) in breast carcinoma. Eur J Cancer, 2002; 38(17): 2252-2257.

McEver RP. Selectin-carbohydrate interactions during inflammation and metastasis. Glycoconj J, 1997; 14(5): 585-591.

Thielemann A, Baszczuk A, Kopczynski Z, Nowak A, Grodecka-Gazdecka S. The clinical usefulness of assessing the concentration of cell adhesion molecules SVCAM-1 and sICAM-1 in the serum of women with primary breast cancer. Contemp Oncol, 2014; 18(4): 252-259.

\section{How to cite this article:}

Ragab HM, Afify M, Samy N, Maksoud NA, Shaaban HM. Evaluation of serum soluble E-selectin in breast cancer. J App Pharm Sci, 2017; 7 (03): 057-061. 